Southern Methodist University

SMU Scholar

\title{
The Obama Administration's New 'REPAYE' Plan for Student Loan Borrowers: Not Much Help for Law School Graduates
}

Gregory S. Crespi

Southern Methodist University, Dedman School of Law

\section{Recommended Citation}

Gregory S. Crespi, The Obama Administration's New 'REPAYE' Plan for Student Loan Borrowers: Not Much Help for Law School Graduates (2016)

This document is brought to you for free and open access by the Faculty Scholarship at SMU Scholar. It has been accepted for inclusion in Faculty Journal Articles and Book Chapters by an authorized administrator of SMU Scholar. For more information, please visit http://digitalrepository.smu.edu. 


\section{THE OBAMA ADMINISTRATION'S NEW "REPAYE" PLAN FOR STUDENT LOAN BORROWERS: NOT MUCH HELP FOR LAW SCHOOL GRADUATES by \\ Gregory Crespi}

Preliminary Draft

May 10, 2016 


\section{ABSTRACT}

In response to President Obama's 2014 directive the Department of Education ("DOE") has promulgated a new student loan repayment option, labeled the Repay As You Earn Plan ("REPAYE Plan"). The REPAYE Plan will be open for enrollment in July of 2016 for up to 6 million student loan borrowers who are not eligible for enrollment in the generous Pay As You Earn Plan ("PAYE Plan") because of their pre-October 1, 2007 federal student loan debts. I estimate in this article that approximately 72,000 of those 6 million persons are law school graduates. However, I also estimate that $62 \%$ of those 72,000 law school graduates, approximately 44,500 persons, have already enrolled in either the Income-Based Repayment Plan ("IBR Plan") or the Income-Contingent Repayment Plan ("ICR Plan"). In addition, most of those among the remaining group of about 27,500 PAYE Plan-ineligible law school graduates who have not already enrolled in a federal loan repayment Plan, if they later do decide to enroll, will choose to enroll in the old IBR Plan rather than in the new REPAYE Plan because of the REPAYE Plan's harsh spousal income inclusion rules.

The largest group of REPAYE Plan law school graduate enrollees in 2016 and afterwords will be those old IBR or ICR Plan enrollees who expect to have relatively modest spousal incomes over the coming two decades, and who consequently will in some instances be able to reduce their monthly repayment obligations by switching over to the REPAYE Plan even given the new spousal income inclusion rules. For the REPAYE Plan to be made more broadly attractive for other law school graduates, especially for those more recent graduates who will increasingly be eligible for PAYE Plan enrollment, the required repayment period for law school graduates would have to be reduced to 20 years and the spousal income inclusion rules eliminated.

Such amendments to the REPAYE Plan rules could be made by the DOE under existing statutory authority and would not require additional Congressional authorization. But the DOE's response to comments made regarding their original proposed rules indicate that such amendments are unlikely because of the politically controversial lost governmental revenue implications, and also because of opposition from those persons within the DOE and elsewhere who regard the existing PAYE Plan's terms as too generous to high-debt graduate school borrowers, and who would not want to see those terms made available to a broader group of law school graduate borrowers. 
TABLE OF CONTENTS

I. INTRODUCTION.

II. EVOLUTION OF THE INCOME-BASED REPAYMENT PLANS FROM THE “OLD” IBR PLAN THROUGH THE REPAYE PLAN

III. THE VERY LIMITED IMPACT OF THE REPAYE PLAN FOR LAW SCHOOL GRADUATES.

A. The PAYE Plan Is A Much Better Alternative Than Is The REPAYE Plan For PAYE Plan-Eligible Law School Graduate Borrowers

B. Most Law School Graduates That Are Not Eligible For PAYE Plan Enrollment But Who Will Be Eligible For REPAYE Plan Enrollment Have Already Enrolled In Either The Old IBR

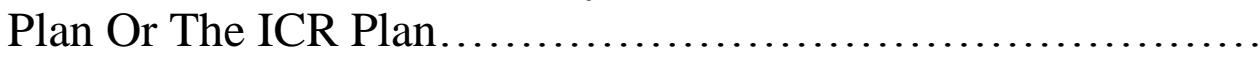

C. The Old IBR Plan Is A Better Alternative Than The REPAYE Plan For Most Law School Graduates.

D. Some Old IBR Plan and ICR Plan Law School Graduate Enrollees Will Switch To The REPAYE Plan......................

E. What Amendments In The REPAYE Plan Would Be Necessary To Make That Plan Attractive To A Broader Group Of Law School Graduates?

IV. CONCLUSION 


\section{INTRODUCTION}

There currently are several federal student loan repayment options available that offer repayment terms that are more favorable to borrowers than are the terms of the standard 10-year amortization schedule. In 1993 Congress initially established the Income-Contingent Repayment Plan (the "ICR Plan"), ${ }^{1}$ and has since supplemented that Plan with several additional income-related repayment Plans, including the original Income-Based Repayment Plan (the "old IBR Plan") that was made available for borrower enrollment on July 1, 2009, ${ }^{2}$ the Pay As You Earn Plan (the "PAYE Plan") that opened for enrollment on December 21, 2012, ${ }^{3}$ and an amended and more generous version of the Income-Based Repayment Plan

1 See generally Omnibus Budget Reconciliation Act of 1993, Pub. L. No. 103-66, Section 4021, 107 Stat. 346 (1993). The Income-Contingent Repayment Plan, made available for borrower enrollment in 1994, requires borrowers to make repayments of $20 \%$ of their "discretionary income," defined as the difference between their adjusted gross income and the poverty level income for a family of their family size, and requires those repayments to be made for 25 years before the remaining debt is forgiven, and allows married borrowers who file separate tax returns to use only their own income and not that of their spouse to determine the size of their repayment obligation. Department of Education, Income-Driven Repayment Plans for Federal Student Loans, Fed. Student Aid, https://studentaid.ed.gov/sites,default/files/income-drivenrepayment.pdf (last visited July 20, 2015). For further discussion of the development and technical aspects of the Income-Contingent Repayment Plan see generally Phillip G.. Schrag, "The Federal Income-Contingent Repayment Option for Law Student Loans," 29 Hofstra L. Rev. 733, 764-74 (2007).

2 College Cost Reduction and Access Act, Pub. L. No. 119-084, Section 203, 121 Stat. 784, 79293 (2007) (now 20 U.S.C. Section 1098(e)).

3 See generally Federal Perkins Loan Program, Federal Family Education Loan Program, and William D. Ford Loan Program, 77 Fed. Reg. 66,088 (Nov. 1, 2012) (codified at 34 C.F.R. Section 685.209(a) (2012)). The PAYE Plan is perhaps best regarded as simply an administrative acceleration to December 21, 2012, under the authority of the statute enacting the earlier Income-Contingent Repayment Plan, see supra n. 1, of the implementation of the "new IBR" plan that under 2010 Congressional legislation, see infra n. 4, was set to go into effect on July 1, 2014 for those IBR-eligible persons who were also "new" borrowers as of that latter date, see infra n. 4. 
(the "new IBR Plan") that became available on July 1, 2014. ${ }^{4}$ Since 2009 many

borrowers have taken advantage of one or another of these new Plans. ${ }^{5}$

Enrollments in the two IBR Plans and especially in the PAYE Plan are now

growing at a striking rate and are likely to continue to grow rapidly in the coming

years, ${ }^{6}$ although there will probably be very few if any new enrollments in the

more restrictive and essentially superseded ICR Plan. ${ }^{7}$

There are, however, a number of borrowers who do not meet the "new

borrower" eligibility criteria of the PAYE $\operatorname{Plan}^{8}$ or of the new IBR Plan ${ }^{9}$ and

4 Health Care and Education Reconciliation Act of 2010, Pub. L. No. 111-152, Sections 22012213, 124 Stat. 1029, 1081 (2010).

5 According to Department of Education statistics as of the start of the second quarter of 2015 there were 600,000 persons enrolled in the ICR Plan, 530,000 enrolled in the PAYE Plan, and 2,330,000 enrolled in the combined old and new IBR Plans. Department of Education, Direct Loan Portfolio by Repayment Plan, Nat. Student Loan Data System, https://studentaid.ed.gov/sites/default/files/fsawg/datacenter/library/DLPortfoliobyRepaymentPla $\underline{\text { n.xls }}$ (last visited July 20, 2015). These DOE statistics are aggregate figures for all Plan enrollees and do not separate out law graduate enrollees from other enrollees.

6 Enrollment in the IBR Plans grew from 910,000 at the start of the third quarter of 2013 to $2,330,000$ by the start of the second quarter of 2015 , a $156 \%$ increase in less than two years. Enrollment in the PAYE Plan grew from only 40,000 at the start of the third quarter of 2013 to 530,000 by the start of the second quarter of 2015, a 1,225\% increase over that time period! Id. Even two years after the PAYE Plan was established it continues to grow rapidly, increasing in enrollments from 410,000 to 530,000 in just the first quarter of 2015, a $29.3 \%$ increase in just one quarter. $I d$.

7 Enrollment in the ICR Plan has been essentially static over the last few years, declining from 630,000 at the start of the second quarter of 2013 down to 600,000 by the start of the second quarter of 2015. Id.

8 Enrollment in the PAYE Plan is only available to borrowers who took out their first federal student loans after October 1, 2007, and who have received a disbursement of a federal student loan after October 1, 2011. Federal Perkins Loan Program, Federal Family Education Loan Program, and William D. Ford Loan Program, 77 Fed. Reg. 66101. Only federal Direct Loans and consolidated Federal Family Education Loans are eligible for PAYE Plan repayment. Id. 9 This new IBR Plan is available only to those IBR-eligible borrowers who are also "new" borrowers as of July 1, 2014 in that they had no outstanding federal Direct Loans or Federal Family Education Loans at that time. 
consequently can enroll only in the less generous old IBR or ICR Plans. To address this concern President Obama in 2014 announced his intention to have the Department of Education ("DOE") take administrative action to make a new loan repayment option available to what the Administration at that time estimated to be up to five million "old borrowers" who do not meet the existing PAYE Plan or new IBR Plan eligibility criteria. ${ }^{10}$ The DOE after subsequent rulemaking negotiations conducted with selected outside parties on April 30, 2015 took a major step towards implementing the President's directive with the promulgation of proposed rules for a Revised Pay As You Earn Plan (the "REPAYE Plan"). ${ }^{11}$ The DOE then on July 9, 2015 issued a Notice of Proposed Rulemaking with regard to the REPAYE Plan. ${ }^{12}$ Those proposed rules then received extensive public comments and were approved in essentially the same form as proposed on October 27,

10 Helping Struggling Federal Student Loan Borrowers Manage their Debt, 79 Fed. Reg. 33, 843 (June 9, 2014); Factsheet: Making Student Loans More Affordable, White House (June 9, 2014), available at https://www.whitehouse.gov/the-press-office/2014/06/09/factsheet-makingstudent-loans-more-affordable. The DOE in their July 9, 2015 Notice of Proposed Rulemaking, Nortice of Proposed Rulemaking, Prop. Edu. Reg., 80 Fed. Reg. 131, at 39608-39641 (July 9, 2015), instead stated that 6 million borrowers would be eligible for the REPAYE Plan, id. at 39627 , although they did not provide supporting data or analysis for new figure. In this article I will hereafter utilize the DOE's 6 million eligible REPAYE borrowers figure.

11 Draft Proposed Modifications to Existing Regulations 4/30/15, Sections 455(d)(1)(D) and 455(e) of the Higher Education Act of 1965, as amended, available at https://www.documentcloud.org/documents/2070469-ed-dept-revised-pay-as-you-earn-repayeproposal.html (last visited August 3, 2015).

1280 Fed. Reg. 131, p. 39608-39641 (July 9, 2015). 
2015. ${ }^{13}$ They will go into effect and the REPAYE Plan will be available for borrower enrollment starting on July $1,2016 .{ }^{14}$

I will focus in this short article on the impact of the new REPAYE Plan upon one particular group of federal student loan borrowers, law school graduates ("law graduates"). I estimate that approximately 72,000 of the estimated six million borrowers who are not eligible for PAYE Plan enrollment because they have taken out federal student loans prior to October 1, 2007, but who will now be eligible for the REPAYE Plan, are law graduates. ${ }^{15}$ This is a particularly significant group

\section{3 [add footnote]}

14 Id. at

15 Let me explain the basis for this estimate. The Department of Education has estimated that 6 million "old borrowers" that are not eligible for the PAYE Plan will be eligible for REPAYE Plan enrollment, see supra n. 10, but it has not in its Notice of Proposed Rulemaking or elsewhere publicly broken down the composition of those 6 million borrowers by the type of degrees awarded, or by the year in which those degrees were awarded. For 2011-12, the latest year for which comprehensive degree-awarded statistics are available, there were a total of 1,017,538 Associate's Degrees awarded, 1,791,046 Bachelor's Degrees awarded, 754,229 Master's Degrees awarded, and 170,062 Doctoral Degrees awarded, for a total of 3,732,875 degrees awarded. National Center for Education Statistics, Bachelor's master's, and doctor's degrees conferred by postsecondary institutions, by field of study: Selected years, 1970-71 through 2011-12, available at https://nces.ed.gov/programs/digest/d13/tables/dt13_318.20.asp (last visited August 3, 2015); National Center for Education Statistics, Associate's degrees conferred by postsecondary institutions, by sex of student and discipline division: 2001-02 through 2011-12, available at https://nces.ed.gov/programs/digest/d13/tables/dt13 321.10.asp (last visted August 3, 2015). Of these 3,732,875 degrees 44,495 were JD or LLB law degrees, ABA Section of Legal Education and Admissions to the Bar, Enrollment and Degrees Awarded 1963-2012 Academic Years, ABA, available at http://www.americanbar.org/content/dam/aba/administrative/legal_education_and_admissions_to the_bar/statistics/enrollmwent_degrees_awarded.authcheckdam.pdf (last visited August 3, 2015). So approximately $(44,495 / 3,732,875)=1.2 \%$ of the total number of degrees awarded in that academic year were three-year law degrees. Absent more detailed and law graduate-specific data I will generalize from this statistic and will assume that also approximately $1.2 \%$ of the 6 million old borrowers who received their degrees distributed over a number of years, and who will now become eligible for REPAYE Plan enrollment - approximately 72,000 persons - will be law graduates. 
because law graduates often have very large combined undergraduate and law school debts - by 2014 averaging approximately $\$ 160,000^{16}$ for the approximately

This is concededly a relatively crude estimation procedure. To the extent that a larger proportion of law graduates take out federal student loans than do persons earning degrees generally, which is very likely, my estimate will to that extent underestimate the number of old borrower law graduates made newly eligible for REPAYE Plan enrollment. On the other hand, to the extent that the 6 million persons made eligible for the REPAYE Plan include persons who took out student loans but did not obtain a degree, which is also very likely, my estimate will to that extent overestimate the number of old borrower law graduates made newly eligible for REPAYE Plan enrollment. Estimation errors that stem from these two causes will therefore fortunately cancel out, at least to some extent.

16 Let me explain the basis for this calculation of $\$ 160,000$ average debt loads among those 2014 law graduates who graduate with student loan debts. The average level of undergraduate debt incurred by persons who borrow to partially finance their undergraduate studies is approximately \$30,000. Jeff Appel (Deputy Under Secretary, Department of Education), Opening Remarks, Pay As You Earn (PAYE) Extension Negotiated Rulemaking Committee Meetings, U.S. Department of Education, 1990 K Street N.W., Eighth Floor Conference Center, Washington, DC 20006 (Feb. 24, 2015). I will assume that law graduates who have borrowed to finance their law studies have on average also borrowed this $\$ 30,000$ amount to finance their undergraduate studies, although it is possible that prospective law students receive on average somewhat more parental financial support for their undergraduate education than do other undergraduate students. As for law school loans, the ABA has estimated the average amount borrowed by law students who took out loans to finance their 2012-2013 law school studies was $\$ 32,289$ for those attending public law schools, and $\$ 44,094$ for those attending private law schools. American Bar Association, 2013 Annual Questionnaire ABA Approved Annual Amount Borrowed: Fall 2013, ABA, available at http://www.americanbar.org/content/dam/aba/administrative/legal_education_and_admissions_to the_bar/statistics/2013_fall_avg_amnt_brwd.xls (last visited August 2, 2015). A simple, unweighted average of these public and private school amounts is $\$ 38,192$ (This is actually a very conservative loan amount estimate because enrollments in private law schools in 2014-15 significantly exceeded enrollments in public law schools by a ratio of 76,282 to 41,802, ABA Task Force on the Financing of Legal Education, Report of the ABA Task Force on the Financing of Legal Education, ABA (June 17, 2015), available at https://www.americanbar.org/content/dam/aba/administrative/legal_education_and_admissions_t o the bar/reports/2015 june_report_of the aba task_force_on the financing_of_legal_educati on.authcheckdam.pdf (;last visited August 3, 2015). Multiplying this one-year average 20122013 law school loan amount estimate by three for the three years of law school from 2011-2012 through 2013-2014 gives an overall sum of \$114,576.

Now if this $\$ 114,576$ of law school loans is taken out on a regularly-spaced basis during the three years of law school then approximately an average of two years will elapse between the taking out of a loan and the borrower's later enrollment in the IBR or PAYE Plan, typically six 
$85 \%$ of recent law graduates who now graduate with loan debts ${ }^{17}$-- and because the much less favorable employment prospects for new attorneys since the 2008 financial crisis will mean that many law graduates will earn only relatively modest incomes for a number of years even if they are able to obtain full-time legal positions. ${ }^{18}$

One would think that these law graduates who are not eligible to make use of the PAYE Plan or the new IBR Plan would benefit from having another available loan repayment option that offers terms that are in some ways more generous than the terms that have been available to them since mid-2009 under the old IBR Plan. The DOE has estimated that 2 million of the estimated 6 million months after law school graduation. I estimate the weighted overall interest rate for these combined undergraduate and graduate student loans to be about 6.44\%. See Gregory Crespi, Should We Defuse the 'Tax Bomb' Facing Lawyers Who Are Enrolled in Income-Based Student Loan Repayment Plans?, [cite to be later added] for discussion of this calculation. At this estimated $6.44 \%$ annual interest rate, which accrues during law school and is added to the debt to be repaid even though the debt repayment obligations do not begin until six months after graduation, this will add another approximately $\$ 114,576 \times 0.1288=\$ 14,757$ to the average borrower's debt (I will not here consider the possible minor additional impact of accrued prePlan enrollment interest on the undergraduate loans of a later law graduate). Adding up these three debt balances $(\$ 30,000+\$ 114,576+\$ 14,757)$ yields a total estimated average law graduate debt at the time of Plan enrollment in 2014 of $\$ 159,333$. For the sake of analytical convenience I will round this estimate up slightly to $\$ 160,000$.

17 William D. Henderson \& Rachael M. Zahorsky, The Law School Bubble: How Long Will It Last if Law Grads Can't Pay Bills?, ABA Journal (Jan. 12, 2012), available at http://www.abajournal.com/magazine/article/the_law_schgool_bubble_how_long_will_it_last_if _law_grads_cant_pay_bills (last visited August 3, 2015).

18 ABA Section of Legal Education and Admissions to the Bar, 2013 Law Graduate Employment Data, ABA available at http://www.americanbar.org/content/dam/aba/administrative/legal_education_and_admissions_to the bar/statistics/2013_law_graduate_employment_data.authcheckdam.pdf (stating that more than $10 \%$ of law graduates are still unemployed nine months after graduation, and another roughly $17 \%$ of those employed are in school-funded positions or employed in jobs that do not require a law degree). 
borrowers not eligible for the PAYE Plan but now made eligible for the REPAYE Plan as of July, 2016 will enroll in that Plan, ${ }^{19}$ a full one-third of those now newly eligible, and they have estimated the overall cost of the REPAYE Plan to the U.S. Treasury from 2016 through 2025 as $\$ 15.3$ billion on that basis. ${ }^{20}$ However, as I will discuss below I have concluded that the new REPAYE Plan, while it may be an attractive option for some borrowers, specifically those persons who have only outstanding undergraduate loans, or who do not envision having substantial spousal income over the coming decades, or both, will not be an attractive option for very many law graduates. I am generally skeptical regarding this estimate that REPAYE Plan enrollments will approach one-third of all of those eligible to enroll who do not qualify for PAYE Plan enrollment, and I am absolutely certain that the rate of enrollment among the approximately 72,000 "old borrower" law graduates not eligible for the PAYE Plan ${ }^{21}$ will be much less than one-third of that number. Unless the rules governing the REPAYE Plan are significantly amended, both with regard to the length of the required repayment period for persons with graduate school loans and with regard to the inclusion of spousal income in determining the required repayment amounts, I believe that relatively few law graduates will find this new Plan to be to their advantage.

19 See supra n. 10 at 39627.

20 The DOE unfortunately did not provide supporting data or analysis for this estimate as to the number of likely REPAYE enrollees or as to the precise basis for this cost estimate in their Notice of Proposed Rulemaking.

21 See supra n. 15. 
In Part II of this article I will describe the recent evolution of the several federal student loan repayment Plans, and I will then outline the terms of the new REPAYE Plan and compare those terms to the terms of the PAYE Plan and of the old and new IBR Plans. In Part III I will discuss why relatively few law graduates are likely to enroll in the REPAYE Plan, and why most of those persons that do enroll in that Plan will be persons who had previously enrolled in the old IBR or ICR Plans and will now elect to change Plans in 2016. I will also discuss what specific amendments to the REPAYE Plan would be necessary to make it an attractive loan repayment option for a broader group of law graduates, and why such amendments are unlikely. Part IV will present a brief conclusion. 


\section{EVOLUTION OF THE INCOME-BASED REPAYMENT PLANS FROM}

\section{THE “OLD” IBR PLAN THROUGH THE REPAYE PLAN}

Since 2009 the federal government has offered a growing menu of relatively generous loan repayment options for persons who have incurred federally-provided or federally-guaranteed student loan debt. In 2007 Congress established what I am referring to as old IBR Plan, which opened for enrollment on July 1, 2009. ${ }^{22}$ That Plan provides eligible borrowers with loan repayment and debt forgiveness terms which are substantially more attractive than are the terms of a much less generous 1993 effort to offer borrowers an income-related loan repayment option through the Income-Contingent Repayment Plan. ${ }^{23}$ Most importantly, the old IBR Plan

22 College Cost Reduction and Access Act, Pub. L. No. 110-84, Section 203, 121 Stat. 784, 792-94 (2007) (codified at 20 U.S.C. Section 1098(e)).

23 See generally Omnibus Budget Reconciliation Act of 1993, Pub. L. No. 103-66, Section 4021, 107 Stat. 346 (1993). The Income-Contingent Repayment Plan requires borrowers to make repayments of $20 \%$ of their discretionary income, and requires those repayments to be made for 25 years before the remaining debt is forgiven, and allows married borrowers who file separate tax returns to use only their own income and not their spouse's income to determine the size of their repayment obligation. Department of Education, Income-Driven Repayment Plans for Federal Student Loans, Fed. Student Aid, https://studentaid.ed.gov/siters/default/files/income-driven-repayment.pdf (last visited July 20, 2015). For further discussion of the Income-Contingent Repayment Plan see generally Phillip G. Schrag, The Federal Income-Contingent Repayment Option for Law Student Loans, 29 Hofstra L. Rev. 733, 764-74 (2007).

The number of persons making loan repayments under the Income-Contingent Repayment Plan decreased slightly from 630,000 in the third quarter of 2013 to 600,000 in the second quarter of 2014, and has remained at that 600,000 level through the start of the second quarter of 2015, showing that there have been few if any new enrollments in that Plan over the past year-and-ahalf now that more generous loan repayment Plans are available. Department of Education, Direct Loan Portfolio by Repayment Plan, Nat. Student Loan Data System, available at 
requires enrollees to make monthly payments that are only equal to $15 \%$ of the difference between the enrollee's adjusted gross income and $150 \%$ of the poverty level income for a family of the enrollee's family size (this difference is hereinafter referred to as the enrollee's "discretionary income"), no matter how large their debt, ${ }^{24}$ and does not require a married enrollee who files a separate tax return from that of their spouse to include their spouse's income in calculating the size of their monthly repayment obligation. ${ }^{25}$ It also adds to the enrollee's debt obligation but does not capitalize into interest-earning principal any unpaid loan interest that accrues during periods of negative amortization when the loan repayments are not sufficient to cover the interest owed on the debt. ${ }^{26}$ Under the old IBR Plan any

https://studentaid.ed.gov/sites/default/files/fsawg/datacenter/library/DLPortfoliobyRepaymentPla n.xls (last visited July 20, 2015).

2420 U.S.C. Section 1098e(a)(3). It is critical to understand that the IBR Plan severs the usual linkage between the size of the debt incurred and the size of the required repayments, dramatically altering borrower incentives. This repayment requirement is subject to the caveat that if an enrollee no longer has a "partial financial hardship" in that the size of his required monthly repayments under the $15 \%$ of discretionary income formula has grown to where it exceeds the amount that he would have owed to repay his debt under a standard 10-year repayment schedule, the enrollee will only for the remainder of the required repayment period (or until the debt is fully repaid) have to make payments equal to that required by a standard 10year repayment schedule for the original amount of loan debt. 20 U.S.C. Section $1098 \mathrm{e}(\mathrm{b})(6)(\mathrm{A})$.

2520 U.S.C. Section $1098 \mathrm{e}(\mathrm{d})$.

2620 U.S.C. Section 1098e(b)(3). This point is subject to two caveats. First, for the first three years after enrollment the federal government will pay any accrued unpaid interest due on subsidized Direct Loans. 20 U.S.C. Section 1098e(b)(3)(A). Second, if an enrollee at some point in time no longer has a "partial financial hardship," see supra $\mathrm{n}$. 4, then at that time any accrued unpaid interest will be capitalized into loan principal and will bear interest for the remainder of the required repayment period (or until the debt is fully repaid). 20 U.S.C. Section 1098e(b)(3)(B)(ii). 
debt remaining after 25 years of repayments is forgiven, ${ }^{27}$ but that forgiven debt is treated by the Internal Revenue Code as taxable income in the year that it is forgiven, potentially triggering substantial tax liability. ${ }^{28}$

The original terms of the old IBR Plan were made substantially more generous for some but not all IBR Plan-eligible borrowers through the issuance of the DOE's PAYE rules, effective December 21, 2012, therefore creating the PAYE Plan as a second loan repayment option. ${ }^{29}$ The most important differences between the PAYE Plan and the old IBR Plan are that PAYE Plan enrollees are required to make payments of only $10 \%$ of their discretionary income, rather than $15 \%$ as under the old IBR Plan, ${ }^{30}$ and now must make those payments for only 20 years, rather than 25 years as under the old IBR Plan, before any remaining unpaid debt is

2720 U.S.C. $1098 \mathrm{e}(\mathrm{b})(7)(\mathrm{B})$.

2826 U.S.C.A. Section 61(a). Internal Revenue Code Section 108 provides some exclusions of cancellation of indebtedness from gross income, in particular the exclusion of student loan debts forgiven after the borrower completes 10 years of qualifying public service employment, 26 U.S.C.A. Section 108, but none of these exclusions apply to debts forgiven under the old IBR Plan, 26 U.S.C.A. 108(f)(1). For an extensive discussion of the multi-billion dollar tax liability consequences for Plan law graduate enrollees of this Internal Revenue Code provision see generally Gregory Crespi. Should We Defuse the 'Tax Bomb' Facing Lawyers Who are Enrolled in Income-Based Loan Repayment Plans?, [cite to be later added].

29 See generally Federal Perkins Loan Program, Federal Family Education Loan Program, and William D. Ford Loan Program, 77 Fed. Reg. 66,088 (Nov. 1, 2012) (codified at 34 C.F.R. Section 685.209(a) (2012). The PAYE Plan is perhaps best regarded as simply an administrative acceleration to December 21, 2012, under the authority of the statute enacting the earlier IncomeContingent Repayment Plan, see supra n. 3, of the implementation of the "new IBR" plan that under 2010 Congressional legislation, see supra n. 4, was set to go into effect on July 1, 2014 for those IBR-eligible persons who were also "new" borrowers as of that latter date.

$30 I d$. at 66,099 . 
forgiven. ${ }^{31}$ Debt forgiven under the PAYE Plan is again treated as taxable income under the Internal Revenue Code. ${ }^{32}$ However, importantly not all persons that are eligible to enroll in the old IBR Plan are also eligible for the PAYE Plan, ${ }^{33}$ nor are all federal loans that are eligible for repayment under the old IBR Plan also eligible for repayment under the PAYE Plan. ${ }^{34}$

Congress also in 2010 legislation ${ }^{35}$ made more generous the terms of the old IBR Plan in a manner that matches the $10 \%$ of discretionary income and 20 -year repayment period terms of the later-implemented PAYE Plan, but these more generous terms are only available for those IBR Plan-eligible persons who are also "new borrowers" as of July $1,2014,{ }^{36}$ thereby establishing yet another loan repayment option which I will hereafter refer to as the "new IBR" Plan. Most law graduates, however, will not be able to make use of the new IBR Plan until at least $2017 .^{37}$

$31 \mathrm{Id}$. at 66,098 .

3226 U.S.C.A. Section 61(a).

33 Enrollment in the PAYE Plan is currently only available to borrowers who took out their loans after October 1, 2007, and who have received a disbursement of a loan after October 1, 2011. See supra n. 29 at 66,089.

34 Only Direct Loans and consolidated Federal Family Education Loans are eligible for PAYE Plan repayment. $I d$. at 66,088.

35 Health Care and Education Reconciliation Act of 2010, Pub. L. No. 111-152, Sections 22012213, 124 Stat. 1029, 1081 (2010).

36 Id. This new IBR Plan is available only to those IBR-eligible borrowers who are also "new" borrowers as of July 1, 2014 in that they had no outstanding Direct Loans or Federal Family Education Loans at that time.

37 The first group of law graduates who will be able to make use of the new IBR Plan to repay all of their law school loan debts will be those persons who first enrolled in law school in 2014 
Let me now turn to the additional loan repayment option will be created by the implementation of the new REPAYE Plan. As I have noted, the rules that will govern that Plan were agreed to on April 30, 2015 by designated DOE officials and outside negotiators who participated in a negotiated DOE rulemaking process in accordance with a Presidential directive, ${ }^{38}$ and were finalized in essentially the same form as proposed after public comment on October $27,2015,{ }^{39}$ and will allow for borrower enrollment starting July $1,2016 .^{40}$

The REPAYE Plan's substantive rules are accompanied by some technical conforming amendments to certain other DOE rules that relate to the IBR or PAYE Plans, ${ }^{41}$ but the REPAYE Plan importantly leaves open as options for eligible borrowers the ability to enroll in any of these other Plans under their existing

with no prior undergraduate federal loan debts, and then took out their first federal student loans in the fall of 2014 for the 2014-2015 academic year, and who then graduate from law school three years later in 2017.

38 The proposed REPAYE Plan is the result of a rulemaking process that was initiated to implement President Obama's June, 2014 directive to the DOE to substantially expand the eligibility for the PAYE Plan to also include a large group of millions of "old" borrowers that are eligible for enrollment in the old IBR Plan but that were not previously eligible to enroll in the more generous PAYE Plan, and to focus the benefits of the new REPAYE Plan on struggling borrowers. See supra n. 10. See also Jeff Appel (Deputy Under Secretary, Department of Education), Opening Remarks, Pay As You Earn (PAYE) Extension Negotiated Rulemaking Committee Meetings, U.S. Department of education, 1990 K Street, N.W., Eighth Floor Conference Center, Washington, DC, 20006 (Feb. 24, 2015).

${ }^{39}$ [add footnote]

40 Draft Proposed Modifications to Existing Regulations 4/30/15, Sections 455(d)(1)(D) and 455(e) of the Higher Education Act of 1965, as amended, available at https://www.documentcloud.org/documents/2070469-ed-dept-revised-pay-as-you-earn-repayeproposal.html (last visited August 3, 2015).

41 See supra n. 11. 
terms. ${ }^{42}$ In other words, the REPAYE Plan will only add another debt repayment option to the existing menu of choices, rather than replace or alter any of these other Plans. The DOE could have attempted to have the new REPAYE Plan rules also apply prospectively to any new enrollees in the PAYE Plan or in either of the IBR Plans, but chose not to do so. I do not know why the DOE made this decision, but it was probably done for both legal and political reasons.

Let me explain this point. As a legal matter, the DOE could have drafted the REPAYE Plan rules to not only apply to REPAYE Plan enrollees but also to apply prospectively to future PAYE Plan enrollees under the discretion given to the DOE by the legal authority conferred by the statutes creating the Income-Contingent Repayment Plan, and in reliance upon which the original PAYE Plan rules were issued. ${ }^{43}$ However, if this sweeping step had been taken the resulting increase in repayment obligations for hundreds of thousands or even millions of future PAYE Plan enrollees over the years because of the REPAYE Plan's spousal income inclusion rules would have far outweighed any benefits conferred on the smaller

42 "The Department [of Education has] stated that it was committed to adding the REPAYE plan to the existing choices of income-driven repayment plans and believed that the current Pay As You Earn repayment plan should be retained until proposed reforms can be implemented that would establish a single income-driven repayment plan targeted to struggling borrowers." See supra $\mathrm{n} .12$ at 39617.

43 Federal Perkins Loan Program, Federal Family Education Loan Program, and William D. Ford Federal Direct Loan Program, 77 Fed. Reg. 42086-01, 42099 (July 17, 2012) (claiming authority for the PAYE rules under Section 455(d)(1)(D) of the Higher Education Act, 20 U.S.C. Section $1089 \mathrm{e}(\mathrm{d})(1)(\mathrm{D}))$. However, an attempt to have the stricter REPAYE rules apply retroactively to prior PAYE Plan or old IBR Plan enrollees would certainly encounter serious legal resistance based on contract law principles. 
group of new REPAYE Plan enrollees, particularly for future graduate enrollees, doubtless leading to serious political controversy and undercutting the increased access to higher education rationale articulated by President Obama in originally calling for DOE action in 2014 to establish a new loan repayment option for borrowers. $^{44}$ It would not only have been similarly politically controversial but also legally problematic for the DOE to attempt to have the REPAYE Plan rules prospectively apply to future old IBR Plan and new IBR Plan enrollees without first obtaining additional Congressional authorization for such action, given the separate statutes that establish the two IBR Plans. But by proposing the REPAYE Plan only as a new Plan that leaves unaltered and available for borrower enrollment all of the previously existing Plans the DOE has avoided these legal and political controversies.

The REPAYE Plan will differ in important ways from each of the existing Plans. Let me discuss the most important differences with regard to law graduates. First of all, the REPAYE Plan rules embrace the PAYE Plan and new IBR Plan provisions that require enrollees to make payments of only $10 \%$ of their discretionary income, rather than the substantially larger $15 \%$ of discretionary income that is required under the old IBR Plan. ${ }^{45}$ Second, they utilize the old IBR

44 See supra n. 10.

45 Draft Proposed Modifications to Existing Regulations 4/30/15, Sections 455(d)(1)(D) and 455(e) of the Higher Education Act of 1965, as amended, available at 
Plan's broad eligibility criteria rather than the more restrictive PAYE Plan or new IBR Plan eligibility criteria, thereby making eligible for enrollment a large group of approximately 6 million student loan borrowers who are not eligible for enrollment under the PAYE Plan or the new IBR Plan, ${ }^{46}$ including an estimated 72,000 law graduates. ${ }^{47}$ Third, the REPAYE Plan will require a loan repayment period of 25 years prior to debt forgiveness, matching the old IBR Plan's 25-year repayment period requirement, for those enrollees who have taken out graduate or professional school loans (and perhaps also undergraduate loans) rather than only undergraduate loans, while requiring only a 20-year loan repayment period prior to

https://www.documentcloud.org/documents/2070469-ed-dept-revised-pay-as-you-earn-repayeproposal.html (last visited August 3, 2015).

46 See supra nn. 8, 9.

47 For 2011-12, the latest year for which comprehensive degree-awarded statistics are available, there were a total of 1,017,538 Associate's Degrees awarded, 1,791,046 Bachelor's Degrees awarded, 754,229 Master's Degrees awarded, and 170,062 Doctoral Degrees awarded, for a total of 3,732,875 degrees awarded. National Center for Education Statistics, Bachelor's master's, and doctor's degrees conferred by postsecondary institutions, by field of study: Selected years, 1970-71 through 2011-12, available at https://nces.ed.gov/programs/digest/d13/tables/dt13 318.20.asp (last visited August 3, 2015); National Center for Education Statistics, Associate's degrees conferred by postsecondary institutions, by sex of student and discipline division: 2001-02 through 2011-12, available at https://nces.ed.gov/programs/digest/d13/tables/dt13 321.10.asp (last visted August 3, 2015). Of these 3,732,875 degrees 44,495 were JD or LLB law degrees, ABA Section of Legal Education and Admissions to the Bar, Enrollment and Degrees Awarded 1963-2012 Academic Years, ABA, available at http://www.americanbar.org/content/dam/aba/administrative/legal_education_and_admissions_to the bar/statistics/enrollmwent_degrees_awarded.authcheckdam.pdf (last visited August 3, 2015). So approximately $(44,495 / 3,732,875)=1.2 \%$ of the total number of degrees awarded in that academic year were three-year law degrees. Absent more detailed and law graduate-specific data I will generalize from this statistic and will assume that also approximately $1.2 \%$ of the 6 million old borrowers who received their degrees distributed over a number of years, and who will now become eligible for REPAYE Plan enrollment - approximately 72,000 persons - will be law graduates. 
debt forgiveness, matching that repayment period imposed by the PAYE and new

IBR Plans, for those enrollees who have taken out only undergraduate loans. ${ }^{48}$

Fourth, only one-half of the unpaid loan interest that accrues for enrollees during

those periods of negative amortization when their required repayments are not

sufficient to pay the interest owing on their loans will be added to their debt, rather

than all of that unpaid interest as is now done under the IBR and PAYE Plans. ${ }^{49}$

48 Draft Proposed Modifications to Existing Regulations 4/30/15, Sections 455(d)(1)(D) and 455(e) of the Higher Education Act of 1965, as amended, available at

https://www.documentcloud.org/documents/2070469-ed-dept-revised-pay-as-you-earn-repayeproposal.html (last visited August 3, 2015). The initial DOE proposal considered by the

REPAYE negotiators had a 20-year repayment period for borrowers whose loan debt was $\$ 57,500$ or less, and a 25-year repayment period for borrowers whose loans exceeded this amount. During the April 28-30, 2015 negotiations, however, primarily because of concerns about creating a sharp "cliff" at this loan amount that would create perverse borrower incentives to inefficiently limit the amount of loan debt this original loan size restriction was changed to the current provision that imposes a 20 -year repayment period for borrowers with only

undergraduate loans, and a 25-year repayment period for borrowers with graduate or professional school loans (and perhaps also undergraduate loans), regardless of the size of the loans involved. Michael Stratford, Income-Based Repayment Expansion Advances, Inside Higher Ed, May 1, 2015, available at https://www.insidehighered.com/news/2015/05/01/federal-rule-making-paneloks-plan-expand-incoime-based-repayment-program (last visited August 3, 2015). That earlier $\$ 57,500$ loan limit would have essentially excluded most law graduates from participation in the Plan.

This current REPAYE rules provision, however, creates another discontinuous "cliff" where even $\$ 1$ of graduate school loan debt will extend an enrollee's debt repayment period on all of their prior undergraduate debts for five additional years, thereby creating a strong and inefficient disincentive to enroll in graduate school. In my opinion it would make far more sense for the DOE to simply impose different length repayment periods for undergraduate versus graduate school loans, a fairly straightforward administrative matter, thus avoiding creating any perverse disincentives with regard to loan amounts or graduate school loans, although this approach would admittedly have some modest lost revenue implications with regard to enrollees with graduate school debts, compared to the current proposed rule.

49 Draft Proposed Modifications to Existing Regulations 4/30/15, Sections 455(d)(1)(D) and 455(e) of the Higher Education Act of 1965, as amended, available at https://www.documentcloud.org/documents/2070469-ed-dept-revised-pay-as-you-earn-repayeproposal.html (last visited August 3, 2015). Under the PAYE and IBR Plans there are provisions 
Fifth, debt forgiven at the end of the required repayment period is regarded as taxable income under the Internal Revenue Code as it is under all of the other Plans. Finally, and very importantly, the REPAYE Plan's rules will require all married enrollees, even those who file separate tax returns from those of their spouse, to now use the couple's combined income for calculating the size of the required monthly repayments, ${ }^{50}$ rather than as is now permitted under the IBR and PAYE Plans for a borrower who files their taxes separately to utilize their income alone for those calculations.

under which the federal government will pay any unpaid interest accruing on subsidized Direct Loans for the first three years after enrollment. 20 U.S.C. Section 1098e(b)(3)(A); 34 C.F.R. 685.209(a)(2)(iii). However, such subsidized loans have not been made available to law students since 2012, and were never available for more than a relatively small proportion of typical law student loan debt, so I will ignore this minor unpaid interest accrual complication in my later illustrative calculations. This particular REPAYE Plan provision to charge borrowers with only one-half of any unpaid interest also raises a potential issue as to whether the forgiveness of the remainder of the unpaid interest creates a tax liability for the enrollee in the year that it is not paid. See infra Part II.

50 Draft Proposed Modifications to Existing Regulations 4/30/15, Sections 455(d)(1)(D) and 455(e) of the Higher Education Act of 1965, as amended, available at https://www.documentcloud.org/documents/2070469-ed-dept-revised-pay-as-you-earn-repayeproposal.html (last visited August 3, 2015). 


\section{THE VERY LIMITED IMPACT OF THE REPAYE PLAN FOR LAW SCHOOL GRADUATES}

For several reasons that I will discuss I believe that relatively few law graduates are likely to enroll in the new REPAYE Plan in 2016 or thereafter. Most law graduates that do enroll in that Plan will be persons who have previously enrolled in the old IBR or ICR Plans who then will switch over to this new Plan in 2016. The repayment period and spousal income inclusion provisions of the REPAYE Plan would each have to be significantly amended for the Plan to become a more broadly attractive option for law graduates, particularly for those law graduates that are eligible for PAYE Plan enrollment, which in my opinion is unlikely to occur. Let me explain these points through several steps of analysis.

F. The PAYE Plan Is A Much Better Alternative Than Is The REPAYE Plan For PAYE Plan-Eligible Law School Graduate Borrowers.

For any law graduate who is eligible for PAYE Plan enrollment that Plan offers significantly better terms than does the REPAYE Plan. Both Plans require repayments of only $10 \%$ of discretionary income, but the PAYE Plan requires

enrollees to make only 20 years of repayments before any remaining debt is forgiven, while the REPAYE Plan requires law graduates to make repayments for 25 years before debt forgiveness. Those final five years of repayments will be 
based on the law graduate enrollee's mid-career salary and for many enrollees could be quite substantial in amount. In addition, under the REPAYE Plan an enrollee must include their spousal income in determining their discretionary income and the size of their required repayments, while under the PAYE Plan an enrollee can use only their income alone for this purpose if they file a separate tax return from that of their spouse, something easily done. ${ }^{51}$ The combined PAYE Plan benefits of the substantially shorter repayment period and, for many married enrollees, the exclusion of significant spousal income will far outweigh the one minor REPAYE Plan advantage over the PAYE Plan of only accruing one-half of unpaid interest during periods of negative amortization into the enrollee's debt obligation, as opposed to accruing all of that unpaid interest into the debt as is done under the PAYE Plan. As a result of the overall much better PAYE Plan terms only those law graduates who are not eligible for enrollment in the PAYE Plan because they have taken out federal student loans prior to October 1, 2007 will even consider REPAYE Plan enrollment. The DOE recognizes this point but understates its significance, certainly with regard to law graduate borrowers. ${ }^{52}$

51 Although an enrollee and their spouse may by filing separate tax returns be subject to less favorable tax brackets for their incomes, and may forego certain deductions or credits available only on joint returns, and may encounter some complications regarding their ability to do this under the PAYE Plan if they reside in a community property state which attributes a spouse's income to the enrollee regardless of their federal tax filing status. 52 "Therefore most borrowers who would be eligible for the PAYE repayment plan or the Income Based Repayment (IBR) Plan as provided for new borrowers after July 1, 2014 would 


\section{B. Most Law School Graduates Who Are Not Eligible for PAYE Plan}

Enrollment But Who Will Be Eligible For REPAYE Plan Enrollment Have Already Enrolled In Either The Old IBR Plan Or The ICR Plan.

The main group of law graduates who may consider REPAYE Plan enrollment will be the approximately 72,000 "old borrower" law graduates first made eligible for enrollment in in that Plan in $2016 .^{53}$ These will primarily be persons who earned their law degrees in 2013 or earlier, and who because of having taken out federal student loans prior to October 1, 2007 are not eligible for PAYE Plan enrollment. ${ }^{54}$ By 2014, however, a large proportion of that year's law school graduates had not started their undergraduate studies until the fall of 2007 and therefore did not incurred any pre-October 1, 2007 federal student loan debts and are eligible for the more generous PAYE Plan. ${ }^{55}$ By 2015 and thereafter even fewer new law graduates each year will have incurred any pre-October 1, 2007

stay in those plans. Many of the borrowers who would choose the REPAYE plan would be from earlier cohorts who were ineligible for the PAYE plan or the IBR Plan for new borrowers after July 1, 2014." See supra n. 12 at 39627 (emphasis added).

53 See supra n. 15.

54 Those law graduates who graduated from law school in 2013 or earlier, and who also took out student loans throughout their four undergraduate years, as is common, will have pre-October1, 2007 loan debts and will therefore be ineligible for PAYE Plan enrollment.

55 The many 2014 law school graduates who took the conventional 4 years undergraduate +3 years law school educational road to a law degree will not have taken out loans to finance their 2007-2011 years of undergraduate education until the fall of 2007, and therefore would qualify for PAYE Plan enrollment. 
federal student loan debts. ${ }^{56}$ So even in the first few years after the REPAYE Plan is made available in 2016 very few recent law graduates will have any reason to consider that option, and the number of REPAYE Plan law graduate enrollments will quickly dwindle to insignificance. Most REPAYE Plan law graduate enrollments that will ever take place will occur in 2016 among members of this initial group of approximately 72,000 law graduates who are not eligible for the PAYE Plan. ${ }^{57}$

However, those 2013 and earlier law graduates that will become eligible for REPAYE Plan enrollment in 2016 all have been eligible for enrollment in the IBR Plan (permitted to enroll any time six months or more after their law school graduation) since mid-2009, and they have been eligible for ICR Plan enrollment since 1994, and I estimate that approximately $62 \%$ of those 72,000 law graduates, approximately 44,500 persons, have already enrolled in one or the other of these two Plans. ${ }^{58}$ Any REPAYE Plan law graduate enrollees in 2016 or thereafter who

56 Among 2015 law school graduates even those persons who took five rather than four years to complete their undergraduate education, from the fall of 2007 through 2012, or who took a year off after receiving their four-year undergraduate degree in 2011 before enrolling in law school, would also qualify for PAYE Plan enrollment.

57 See supra n. 15.

58 By the end of 2014 2,070,000 persons had enrolled in the old IBR Plan, see supra $\mathrm{n}$. 5, and I estimate that by the end of 2015 another 1,040,000 will do (260,000 old IBR enrollees in the first quarter of $2015, \mathrm{x} 4, i d$.), for a total of 3,110,000 old IBR Plan enrollees by the end of 2015. I estimate that $1.2 \%$ of these old IBR Plan enrollees are law graduates, see supra n. 15, for a total of at least 3,110,000 x.012 =37,320 old IBR Plan law graduate enrollees. In addition, there were 600,000 persons enrolled in the ICR Plan by the end of 2014, and I similarly estimate that $1.2 \%$ of those enrollees, a total of $600,000 \times .012=7,200$ enrollees, were law graduates. So by 
were not previously enrolled in the old IBR or ICR Plans will be drawn from the remaining small pool of approximately 27,500 or so ${ }^{59} 2013$ or earlier law graduates who are not eligible for PAYE Plan enrollment, and who have thus far declined to enroll in another Plan.

C. The Old IBR Plan Is A Better Alternative Than The REPAYE Plan For Most Law School Graduates.

Even among this relatively small group of 2014 or earlier law graduates who are not eligible for PAYE Plan enrollment, and who have not enrolled in either the old IBR or ICR Plans, most of those persons if they do eventually choose to enroll in a Plan are likely to select the old IBR Plan rather than the new REPAYE Plan. Let me explain why.

Both the old IBR Plan and the REPAYE Plan will require 25 years of loan repayments by law graduate enrollees. However, the REPAYE Plan has the advantage over the old IBR Plan in that it will require that the enrollee make repayments of only $10 \%$ of their discretionary income, while the old IBR Plan will require larger repayments of $15 \%$ of discretionary income. In addition, under the REPAYE Plan the federal government will forgive one-half of any unpaid accrued

my estimate $37,320+7,200=44,520$ law graduates, a full $61.8 \%$ of the estimated 72,000 law graduates that are not eligible for PAYE Plan enrollment and that will now be eligible for REPAYE Plan enrollment, have already enrolled in either the old IBR Plan or the ICR Plan. $5972,000 \times(100 \%-61.8 \%)=27,504$. See id. 
interest during periods of negative amortization, while the old IBR Plan it will not do so. On the other hand, and very importantly, under the REPAYE Plan a married enrollee will have to include any spousal income in determining their size of their discretionary income, which could increase those required repayments quite substantially, whereas an old IBR Plan enrollee will not have to do this if they file a separate tax return.

This choice between these two Plans can be fairly precisely analyzed. If a prospective Plan enrollee has a spouse whose future adjusted gross income is expected to increase the family's discretionary income by less than $50 \%$ each year, on average, the REPAYE Plan will then require on average smaller monthly repayments than will the old IBR Plan. But if the expected spousal adjusted gross income will on average increase the family's discretionary income by more than $50 \%$ each year, however, the old IBR Plan will prove more advantageous, assuming that the enrollee files a separate tax return. ${ }^{60}$ As a rough rule of thumb, if

60 If an enrollee's spousal income increases the family's discretionary income by exactly $50 \%$, then the REPAYE Plan's required repayments of $10 \%$ of that larger family discretionary income will be exactly equal in size to the required repayments made under the old IBR Plan's requirement of $15 \%$ of the amount of discretionary income based only on the enrollee's adjusted gross income. If the spousal income increases the family's discretionary income by less than $50 \%$ there will therefore be some benefit to old IBR Plan enrollees of switching to the REPAYE Plan. Some but not all of the savings in lower repayments that an old IBR enrollee might obtain by switching to the REPAYE Plan may be offset by a larger debt forgiveness tax liability obligation eventually imposed because of a larger amount of debt forgiven, although the amount of additional tax liability imposed will be limited by the more favorable REPAYE unpaid interest accrual provisions. If, on the other hand, an old IBR Plan enrollee has sufficient spousal income that their payments would be increased by switching to the REPAYE Plan the preferable choice 
the enrollee's spouse's expected annual adjusted gross income will average more than about $33 \%$ of the enrollee's adjusted gross income over the entire required repayment period this will increase the REPAYE Plan repayment requirements sufficiently that the old IBR Plan will prove more advantageous to the enrollee. ${ }^{61}$ Many law graduates have or eventually will have relatively well-educated spouses who will be working full-time for a number of years and will earn fairly substantial incomes, often as much or more than $33 \%$ of the enrollee's income. As a result many if not most of this small initial group of approximately 27,500 potential REPAYE Plan law graduate enrollees that are not eligible for the PAYE

would be for that person to remain enrolled in the old IBR Plan, although the financial advantage of doing so would be reduced somewhat by the REPAYE Plan's more favorable unpaid interest accrual provisions. For detailed discussion of the tax liability aspects of the different Plans see generally Gregory Crespi, supra n. 28.

61 As an illustration of this point, consider a 2016 old IBR Plan enrollee with a $\$ 75,000 /$ year adjusted gross income, about the average income for a new law graduate that year, and a family size of three persons. That person will have a discretionary income of approximately $(\$ 75,000 /$ year - \$30,000/year $)=\$ 45,000 /$ year, and will therefore under the old IBR Plan will have to make required monthly repayments of $((\$ 75,000-\$ 30,000) / 12) \times .15=\$ 563 / \mathrm{month}$. Under the REPAYE Plan it would require a family discretionary income of $\$ 67,500$ year to have the same required monthly repayment obligation of $\$ 563$. $(\$ 67,500 / 12) \times \cdot 10=\$ 563$. Therefore if the enrollee's spouse has an adjusted gross income of more than $\$ 22,500 /$ year -- more than $30 \%$ of the enrollee's $\$ 75,000 /$ year adjusted gross income -- the REPAYE Plan will then be more costly than the old IBR Plan for that enrollee. If that 2016 old IBR Plan enrollee instead had an AGI of \$100,000/year he would benefit from shifting to the REPAYE Plan unless his spouse had an AGI of more than $\$ 35,000,35 \%$ of the enrollee's AGI.

As a general rule of thumb, therefore, the spousal income cut-off line where shifting from the old IBR Plan to the REPAYE Plan is no longer to the enrollee's advantage is approximately $33 \%$ of the enrollee's AGI. I ignore in this calculation the possibility that an enrollee's family may bear some additional tax liability by having the enrollee and their spouse file separate tax returns rather than filing a single joint tax return and therefore possibly lose some deductions or credits or face less advantageous tax bracket cut-offs. 
Plan, and who have not previously enrolled in either the old IBR Plan or the ICR Plan, will probably choose the old IBR Plan over the new REPAYE Plan if they do elect to enroll in a Plan in 2016, although it is difficult to predict exactly what the relative enrollment proportions between these two Plans are likely to be among those enrollees. After 2016, as I have discussed, a larger and larger proportion of new law graduates will be eligible each year for PAYE Plan enrollment, eventually approaching 100\%, and the relative merits of the old IBR and REPAYE Plans as compared to one another will become irrelevant to a larger and larger proportion of law graduates each year who will choose the PAYE Plan if they do enroll. The number of new old IBR Plan and REPAYE Plan enrollments will quickly dwindle to insignificance after 2016.

D. Some Old IBR Plan and ICR Plan Law School Graduate Enrollees Will Switch To The REPAYE Plan

As I have discussed above, for several reasons probably only a few of the approximately 27,500 or so law graduates that are not eligible for PAYE Plan or new IBR Plan enrollment, and that will become eligible for REPAYE Plan enrollment in July of 2016, and who have not previously enrolled in either the old IBR or ICR Plans, ${ }^{62}$ will do so. It is, however, likely that some significant fraction of the approximately 44,500 law graduates not eligible for PAYE Plan enrollment 62 See supra nn. 56, 57. 
that I estimate have or will have enrolled in either the old IBR or ICR Plans by the end of $2015^{63}$ and any additional persons who enroll in one of these Plans during the first six months of 2016 will not expect to have significant spousal income over the coming two decades. These Plan enrollees may elect to change their Plan enrollment in 2016 from the old IBR Plan or the ICR Plan to the REPAYE Plan in order to take advantage of the lower $10 \%$ of discretionary income monthly repayment requirement of the REPAYE Plan to reduce their monthly repayments, ${ }^{64}$ which will then decline by as much as one-third if they have no spousal income at all and were enrolled in the old IBR Plan, ${ }^{65}$ and by as much as one-half if they were enrolled in the ICR Plan. ${ }^{66}$

I do not have the detailed family income profile information for attorneys for the first 25 years of their careers that would be necessary to estimate with any confidence the proportion of these old IBR or ICR Plan law graduate enrollees that will have sufficiently low expected spousal incomes to motivate them to switch to the new REPAYE Plan, but conceivably several thousand or perhaps even ten

$63 \mathrm{Id}$.

64 There is the one complication that if old IBR or ICR Plan enrollees switch to the REPAYE Plan any unpaid interest that has accrued under their old Plan will now be capitalized fror purposes of the REPAYE Plan. This is not likely to be a problem for ICR Plan enrollees, but some old IBR Plan enrollees may have fairly significant amounts of unpaid accrued interest in 2016 that may deter to some extent their changing Plans.

$6510 \% / 15 \%=.667$.

$6610 \% / 20 \%=.50$. 
thousand or more of what I estimate to be about 45,000 such enrollees ${ }^{67}$ may do so in 2016. These persons changing Plans will clearly be the largest group of law graduates who will benefit to some extent from the implementation of the REPAYE Plan, although I doubt that the new Plan's rules were formulated with these existing old IBR and ICR Plan law graduate enrollees in mind. I would expect that the large majority of changes to REPAYE Plan enrollment by existing old IBR or ICR Plan law graduate enrollees will take place in the second half of 2016 at the first opportunity for those persons to realize these repayment savings, although some few old IBR or ICR Plan enrollees who do not make this change in 2016 might do so at a later date if there are subsequent changes in the current income or future income prospects of their spouses that would now make the REPAYE Plan alternative more attractive than continuing with their existing Plan.

E. What Amendments In The REPAYE Plan Would Be Necessary To Make That Plan Attractive To A Broader Group Of Law School Graduates?

As I have noted above, over time a greater and greater proportion of new law graduates will be eligible each year for PAYE Plan enrollment. Therefore any amendments to the REPAYE Plan that would make it a more attractive option than the old IBR Plan, but that would still leave the REPAYE Plan as an inferior choice to the PAYE Plan, would not suffice to induce significant REPAYE Plan

67 See supra $\mathrm{n} .57$. 
enrollment by new law graduates. For example, eliminating the requirement that spousal income be included in establishing the size of the required repayments, while still leaving the required repayment period at 25 years for law graduates, would also still leave the REPAYE Plan an inferior choice to the PAYE Plan for those law graduates that are eligible for that latter Plan. Similarly, reducing the length of the required repayment period for law graduates to 20 years to match the PAYE Plan requirements, while still leaving in force the REPAYE Plan's spousal income inclusion rules, would still leave the REPAYE Plan an inferior choice to the PAYE Plan for those law graduates who expected to have any spousal income at all over the following two decades.

Consider, however, if the REPAYE Plan's rules were significantly amended to both reduce the repayment period for law students to the same 20 years now required for undergraduate loan-only borrowers, and to eliminate the inclusion of spousal income in determining the size of repayment obligations. Then the REPAYE Plan would now be slightly more attractive than the PAYE Plan for prospective Plan enrollees that are eligible for either Plan, since it would now match the key required repayment amount and repayment period length of the PAYE Plan, and it would still have a more favorable unpaid interest accrual provision than that of the PAYE Plan. Those changes would also make the REPAYE Plan much more advantageous than the old IBR Plan and the ICR Plan 
for those "old borrowers" that are not eligible for enrollment in the PAYE Plan since it would both reduce the length of the required repayment period by five years and reduce the size of the required repayments by one third for old IBR enrollees, and by one-half for ICR enrollees.

If such an amendment was made to the REPAYE Plan rules this would have several major effects that would be beneficial for many law graduates. First, consider those approximately 27,500 or so 2013 or earlier law graduates that are not eligible for PAYE Plan enrollment, and are also not enrolled in the old IBR or ICR Plans. If those persons do decide to enroll in a Plan they would then enroll in the REPAYE Plan rather than in the old IBR Plan. Second, virtually all current old IBR or ICR Plan law graduate enrollees would immediately switch over to the REPAYE Plan since they could thereby significantly reduce size of their repayment obligations, by one-third for the old IBR Plan enrollees and by one-half for the ICR enrollees, and also reduce the length of their required repayment period by five years, without any significant offsetting drawbacks. ${ }^{68}$ Third, probably most of those many law graduates who are eligible for PAYE Plan enrollment would now instead enroll in the now roughly comparable REPAYE Plan that would be preferable because of its more favorable negative amortization interest accrual provisions, provisions which are particularly important to high-debt law

68 But see supra $\mathrm{nn} .59,60$. 
graduates. ${ }^{69}$ Finally, there would even be some switching of high-debt PAYE Plan enrollees to the REPAYE Plan, again because of the now essentially identical repayment terms and the REPAYE Plan's more favorable treatment of unpaid interest during periods of negative amortization. The REPAYE Plan would become the preferred loan repayment alternative for all law graduates seeking an income-based loan repayment option, and enrollments in 2016 and thereafter would grow rapidly.

Such amendments to the REPAYE Plan that would make it this attractive to law graduates could be made, but I am personally not optimistic on this score. First of all, some commentators have criticized the IBR Plans and especially the PAYE Plan on distributional grounds, as being too generous to high-debt graduates of law school and other graduate school programs relative to the much smaller payment reduction and especially debt forgiveness benefits that those Plans offer for undergraduate borrowers with much smaller loan debts. ${ }^{70}$ Those persons probably regard the REPAYE Plan's extended repayment period for graduate

69 See generally Crespi, supra n. 28.

70 See Jason Delisle and Alexander Holt, A Student Loan Blind Spot, The Washington Post, February 20, 2015, available at https://www.washingtonpost.com/opinions/the-22-billionstudent-loan-blind-spot/2015/02/20/e3413e82-b6f5-11e4-aa05-1ce812b3fdd2_story.html (last visited August 3, 2015); see also On the Backs of Students and Families, American Federation of Teachers, 2012, available at http://www.aft.org/sites/default/files/studentdebt0613.pdf (last visited August 3, 2015). In its Notice of Proposed Rulemaking the DOE took the position that requiring REPAYE Plan borrowers to include spousal income in determining their required repayment amounts was "more equitable" than not doing so, despite the contrary provisions of the ICR and IBR and PAYE Plans that do not require the inclusion of spousal income, see supra n. 14 at 39618, suggesting that the DOE is also of this view. 
student borrowers and its spousal income inclusion rules as needed corrections to the overly generous PAYE Plan provisions that would not introduce unintended distortions of incentives. ${ }^{71}$ Second, such amendments to the REPAYE Plan that made it so attractive to law graduates and other high-debt graduate school borrowers would of course be costly to the Treasury in terms of reduced student loan repayments, particularly with regard to the probably many old IBR Plan or ICR Plan enrollees who would reduce the size of their repayments, by one-third for old IBR enrollees and one-half for ICR enrollees, and also shorten their repayment periods by five years. ${ }^{72}$

71 The original version of the REPAYE Plan proposed for discussion by the DOE had a stringent $\$ 57,500$ cap on the amount of loan debt that could be repaid under the Plan, a different sort of restriction on high debt graduate school borrowers that would have essentially excluded law graduates from participating in the REPAYE Plan, Draft Proposed Modifications to Existing Regulations 4/30/15, Sections 455(d)(1)(D) and 455(e) of the Higher Education Act of 1965, as amended, available at https://www.documentcloud.org/documents/2070469-ed-dept-revised-payas-you-earn-repaye-proposal.html (last visited August 3, 2015), but this cap was later dropped in favor of the longer 25-year repayment period imposed upon enrollees with graduate school debt.

72 This DOE appears to be quite sensitive to the lost governmental revenue implications of any relaxation of the REPAYE rules relating to graduate school borrowers, particularly given their lost revenue estimates for 2016-2025 along for the REPAYE Plan as now proposed of $\$ 15.3$ billion, see supra n. 14 at 39627, rejecting in the negotiations as having "unacceptably high" costs to taxpayers a compromise proposal that would have reduced the required repayment period to 20 years for only the undergraduate loans taken out by a borrower who had also taken out loans for graduate or professional studies. See supra n. 14 at 39622 . Such a measure would of course have far smaller lost revenue implications that would reducing the repayment period to 20 years for all loans taken out by graduate or professional school borrowers.

The amount of revenue that would be lost to the government by such major changes in the REPAYE Plan rules as I here suggest are rather difficult to estimate. One complication here is that some fraction of the loan repayment revenues that are lost each year by the federal government when old IBR or ICR enrollees switched over to the REPAYE Plan under these amended terms for the remainder of their required repayment period would be recaptured by the 
However, those persons favoring such a significant amendment of the REPAYE Plan rules that would greatly favor law graduates and other high-debt graduate and professional school borrowers can argue that the DOE has not proposed the REPAYE Plan as a measure that will prospectively displace the IBR or PAYE Plans for future enrollees, as those persons critical of the generosity of the PAYE Plan provisions might favor, but has merely provided another alternative Plan choice, although as the rules now stand it will be a choice that as I have demonstrated will be an irrelevant alternative that will be ignored by almost all law graduates except for those few old IBR Plan or ICR Plan law graduate enrollees with relatively small spousal incomes who may elect to change their Plan enrollment. Given that the choice has been made by the DOE to allow the PAYE Plan and new IBR Plan to continue to be available for law graduates alongside the new REPAYE Plan, ${ }^{73}$ a plausible argument can be made that the two substantial modifications that I suggest to the REPAYE Plan rules that would allow the shrinking pool of "old borrowers" among the new law graduates that are not government at the time of debt forgiveness, since with the smaller repayments and shorter repayment period many REPAYE Plan law graduate enrollees would have a significantly larger amount of debt forgiven when they qualified for debt forgiveness, and therefore would owe substantially more in federal and state income taxes on that larger forgiven debt. For a comprehensive discussion of the tax liability aspects of all of the different Plans, see generally Crespi, supra n. 28.

73 Although the DOE's comments in their Notice of Proposed Rulemaking suggests that they regard the REPAYE Plan and all of the other existing Plans as merely stopgap measures until reform legislation is adopted that replaces all of the existing Plans with a single income-driven repayment Plan that is closely modeled upon the REPAYE Plan's "struggling borrower"oriented required repayment period and spousal income inclusion provisions. See supra n. 10 at 39617. 
currently eligible for PAYE Plan enrollment to enter into loan repayment arrangements on virtually the same generous PAYE Plan-type terms that are now available to all post-October 1, 2007 borrowers would be the fairest way to proceed. $^{74}$

Since the REPAYE Plan is being promulgated as a DOE administrative action, under the DOE's existing legislative authority under the 1993 statute establishing the ICR Plan, these amendments could be made to those Plan rules without the need for further Congressional action. This is a major advantage for achieving such changes, given the current highly partisan Congressional gridlock, particularly with regard to proposals with significant governmental revenue implications. However, such a substantial change in the federal student loan repayment framework that this amended REPAYE Plan would bring about would certainly lead to Congressional efforts to amend the ICR statute to preclude such action, although again such efforts might well founder due to the gridlock situation, although in this case the blockage would likely resulting from Democratic opposition rather than the currently more common Republican resistance to legislative initiatives.

74 Although a likely DOE response to this argument would be that while consistency of treatment does promote fairness, the terms that are ideally consistently applied should resemble more the restrictive proposed REPAYE Plan terms than the more generous PAYE Plan terms. 
But even though the Obama Administration could probably force implementation of the REPAYE Plan with such significant DOE amendments as I suggest over Congressional opposition I do not expect that such amendments to the REPAYE Plan rules will be made, partly because of the political resistance they would engender and partly because of the lost federal revenues, already estimated by the DOE as $\$ 15.3$ billion for the $2016-2025$ period for that Plan even absent the liberalizing amendments that I have suggested. ${ }^{75}$ In fact, I suspect that alternatives to the current REPAYE Plan rules along the general lines that I have suggested of more closely replicating the PAYE Plan's terms were vigorously discussed at the highest policy levels and then rejected, both prior to the promulgation of the original draft rules and again in response to the comments received. The REPAYE Plan in its current form will not benefit very many law graduates, probably only the relatively small number of old IBR or ICR Plan-enrollees who have relatively small current and expected future spousal incomes and who then choose to shift their Plan enrollment to the REPAYE Plan.

75 See supra n. 10 at 39627. 


\section{CONCLUSION}

In response to President Obama's directive the DOE has proposed a new student loan repayment option labeled the REPAYE Plan which will be open for enrollment in July of 2016 to up to 6 million student loan borrowers who are not eligible for enrollment in the generous PAYE Plan. I estimate that approximately 72,000 of those 6 million persons are law graduates. However, I also estimate that approximately $62 \%$ of those 72,000 law graduates, approximately 44,500 persons, will have already enrolled in either the old IBR Plan or the ICR Plan. Most of those among the remaining group of about 27,500 PAYE Plan-ineligible law graduates that have not already enrolled in a Plan, if they later do decide to enroll, will enroll in the old IBR Plan rather than the new REPAYE Plan because of the latter Plan's spousal income inclusion rules.

The largest group of REPAYE Plan law graduate enrollees in 2016 will be those relatively few current old IBR Plan or ICR Plan enrollees who have or who expect to have relatively modest spousal incomes over the coming two decades, and who consequently will be able to reduce their monthly repayment obligations by switching over to the REPAYE Plan. For the REPAYE Plan to be made more broadly attractive to other law graduates, especially to those law graduates eligible for PAYE Plan enrollment, the required repayment period would have to be reduced to 20 years and the spousal income inclusion rules eliminated. Such a 
significant amendment to the REPAYE Plan's rules was called for by some commentators responding to the originally proposed rules. However, such suggestions were rejected, probably because of the lost governmental revenue implications, and also because of opposition from those persons who regard the existing PAYE Plan's terms as too generous to high-debt graduate school borrowers, and who would not want those terms made available to a broader group of law graduate borrowers. 